
\title{
R Reserach S Suare \\ Euxinic versus ferruginous anoxia before and during the Toarcian Oceanic Anoxic Event
}

\section{Alexandra Kunert ( $\nabla$ akunert@uwaterloo.ca )}

University of Waterloo

\section{Brian Kendall}

University of Waterloo

\section{Article}

Keywords:

Posted Date: January 26th, 2022

DOI: https://doi.org/10.21203/rs.3.rs-967493/v1

License: (c) (1) This work is licensed under a Creative Commons Attribution 4.0 International License. Read Full License

Version of Record: A version of this preprint was published at Nature Communications on February 13th, 2023. See the published version at https://doi.org/10.1038/s41467-023-36516-x. 


\section{Abstract}

Mesozoic oceanic anoxic events are recognized as widespread deposits of marine organic-rich mudrocks temporally associated with mass extinctions and large igneous province emplacement. The Toarcian Oceanic Anoxic Event (T-OAE) is one example during which expanded ocean anoxia is hypothesised in response to environmental perturbations associated with emplacement of the Karoo-Ferrar igneous province. However, the global extent of total seafloor anoxia and the relative extent of ferruginous (anoxic and Fe2+-rich) versus euxinic (anoxic and H2S-rich) conditions during the T-OAE and other Mesozoic OAEs are poorly constrained. Here we present new estimates of the global anoxic and euxinic seafloor area before and during the T-OAE based on rhenium and molybdenum enrichments in organic-rich mudrocks of the Fernie Formation (British Columbia, Canada). Trace metal concentrations and ratios, together with high organic carbon contents, indicate that this previously unstudied locality was minimally restricted from global ocean circulation, experienced deep-water nutrient upwelling, and had 02-deficient bottom waters. Pronounced rhenium and molybdenum enrichments in mudrocks deposited from locally anoxic and euxinic waters, respectively, point to large global oceanic reservoirs of these metals. Mass balance models suggest that the T-OAE likely comprised a modest expansion of up to $~ 7 \%$ anoxic seafloor dominated by euxinia. Hence, anoxic seafloor was likely confined to epicontinental seaways, semi-restricted basins, and continental margin oxygen minimum zones during the T-OAE.

\section{Main}

The ca. 183 Ma Toarcian Oceanic Anoxic Event (T-OAE) represents a significant perturbation to Earth's atmosphere-ocean system and was associated with a global mass extinction ${ }^{1,2}$. The $300-500 \mathrm{kyr}$ event $^{3-5}$ coincides with and is thought to have been triggered by emplacement of the subaerial KarooFerrar large igneous province (LIP) in southern Pangea ${ }^{1,3,6}$. The environmental perturbances triggered by LIP emplacement included a dynamic climate ${ }^{7-9}$, enhanced hydrological cycle and continental weathering ${ }^{9-11}$, increased organic productivity ${ }^{3}$, and a significant expansion of seafloor anoxia and euxinia ${ }^{12,13}$. Despite the OAE naming convention which emphasizes the importance of expanded seafloor anoxia, the global extent of bottom water anoxia $\left(\left[\mathrm{O}_{2}\right]_{\mathrm{aq}}=0 \mathrm{ml} / \mathrm{l}\right)^{14}$ across the T-OAE remains poorly constrained, as is the relative extent of ferruginous anoxia ( $\mathrm{Fe}^{2+}$-rich bottom-waters) and euxinic anoxia ( $\mathrm{H}_{2} \mathrm{~S}$-rich bottom-waters).

The global extent of ocean euxinia during the T-OAE has been inferred from molybdenum isotope compositions $\left(\delta^{98} \mathrm{Mo}\right)$ in organic-rich mudrock (ORM). When the oceans are primarily well-oxygenated, manganese oxides enriched in lighter-mass Mo isotopes are buried over a larger portion of the seafloor, resulting in global seawater with a higher $\delta^{98} \mathrm{Mo}$. By contrast, the low $\delta^{98} \mathrm{Mo}$ of locally euxinic ORM from multiple sections in Europe suggest that global seafloor euxinia expanded and oxic seafloor contracted during the early stages of the T-OAE ${ }^{15-17}$. Euxinic waters have been estimated to cover $2-10 \%$ of the Toarcian seafloor, which is one to two orders of magnitude greater than the modern ocean ( 0.1$0.2 \%)^{15,17,18}$. However, suggestions that the Toarcian sections of Europe were deposited in sedimentary 
basins highly restricted from global ocean circulation have called these interpretations into question ${ }^{8,19-21}$. Importantly, Mo isotope data do not reliably constrain the extent of ferruginous seafloor because the magnitude of isotope fractionation during Mo removal to sediments under $\mathrm{Fe}^{2+}$-rich bottom waters overlaps with fractionations observed for Mo burial in weakly euxinic to mildly oxygenated settings ${ }^{22}$.

Thallium isotope compositions $\left(\varepsilon^{205} \mathrm{TI}\right)$ from ORM have also been applied to reconstruct the global ocean redox landscape during the T-OAE. Preferential burial of isotopically heavy $\mathrm{Tl}$ adsorbed to $\mathrm{Mn}$ oxides deposited in well-oxygenated seafloor sediments shifts seawater $\varepsilon^{205} \mathrm{TI}$ towards lighter values, whereas limited areas of oxic seafloor will shift seawater to heavier values. In the early Toarcian, two distinctive shifts towards heavier $\varepsilon^{205} \mathrm{TI}$ are captured in ORM from western Canada, one $\sim 500 \mathrm{kyr}$ before a negative carbon isotope excursion (N-CIE) and another at the onset of the $\mathrm{N}-\mathrm{CIE}$, which are thought to indicate two expansions of ocean anoxia ${ }^{23}$. The highest $\varepsilon^{205} \mathrm{TI}$ values at the onset of the N-CIE indicate that burial of $\mathrm{Mn}$ oxides decreased by at least $50 \%$ during the T-OAE, suggesting an equivalent increase of weakly-oxygenated, ferruginous, and/or euxinic bottom waters ${ }^{23}$. However, the $\mathrm{Tl}$ isotope proxy does not deconvolve the relative seafloor areas covered by these three $\mathrm{O}_{2}$-deficient redox settings.

An alternative approach to quantify the overall extent of oceanic anoxia-including ferruginous seafloorduring the T-OAE is required. Here, we apply a recently developed elemental mass balance model ${ }^{24}$ that uses rhenium and Mo enrichments from Pliensbachian to Toarcian ORM (Gordondale Member, Fernie Formation, British Columbia, Canada; Figure 1) to quantitatively estimate total anoxic seafloor area (euxinic plus ferruginous) and total euxinic seafloor area, respectively, before and during the T-OAE. Both Re and Mo are ideal trace metals to quantify the global redox conditions in the oceans due to their conservative behaviour in oxygenated seawater, long ocean residence time (130-440 kyr today ${ }^{25}$, and low detrital background in organic-rich marine sediments ${ }^{18,24}$. High Re burial rates, and thus $\operatorname{Re}$ enrichments, in marine sediments occur in both ferruginous and euxinic environments via complexation of Re with organic matter and sulfide minerals ${ }^{26}$, but negligible Re enrichment occurs in oxygenated sediments. Molybdenum preferentially forms thiomolybdate complexes in the presence of dissolved $\mathrm{H}_{2} \mathrm{~S}$ and the burial efficiency of sulfurized Mo species in euxinic sediments is significantly elevated compared to Mo burial in non-euxinic settings.

These distinctive redox characteristics mean that a predominantly well-oxygenated global ocean will have large dissolved reservoirs of Re and Mo sourced from rivers, and thus pronounced enrichments will occur in ORM that cover small areas of the open ocean within oxygen minimum zones on continental margins. By contrast, an expansion of anoxic and euxinic marine sediment sinks will draw down the dissolved oceanic Re and Mo reservoirs, respectively, leading to muted enrichments in ORM deposited in unrestricted marine settings ${ }^{18,24}$. Using these principles, Re and Mo oceanic mass balance models can be used to infer the extent of seafloor anoxia and euxinia, respectively, using their enrichments in locally anoxic or euxinic ORM deposited in unrestricted marine settings. The extent of ferruginous seafloor can be calculated as the difference between the total anoxic and euxinic seafloor areas. 


\section{Local paleoenvironmental setting of the T-OAE in British Columbia}

The T-OAE is expressed globally by synchronous deposits of ORM recording a N-CIE in organic and carbonate carbon, embedded within a broader positive $\mathrm{CIE}^{27-33}$. The T-OAE was identified in the Red Deer Member (Fernie Formation) of Alberta, Canada in cores (1-35-62-5W6 and 6-32-75-20W5) and outcrop (Bighorn Creek East Tributary) by a $\mathrm{N}-\mathrm{CIE}$ with a magnitude of $-3 \%$ o to $-4 \%{ }^{27,34}$. We report new elemental and organic carbon isotope data $\left({ }^{13} \mathrm{C}_{\mathrm{org}}\right)$ from a drill core (c-B6-A/94-B-8) in British Columbia, Canada, that hosts equivalent Fernie Formation strata (Gordondale Member). This core contains the N$\mathrm{CIE}$ across a vertical interval of $7.1 \mathrm{~m}$ and has a magnitude of -2.0 to $-2.4 \%$ o (Figure 2). Using this $\delta^{13} \mathrm{C}_{\text {org }}$ profile, the Gordondale Member can be subdivided into Pre N-CIE (>1582.10 m), N-CIE (1582.10$1575.00 \mathrm{~m})$ and Post N-CIE $(<1575.00 \mathrm{~m})$ intervals. A second N-CIE is observed below $1587.00 \mathrm{~m}$ but may represent an older Sinemurian or Pliensbachian event ${ }^{34,35}$. Direct age constraints are not available within the study core, however, detailed litho- and chemostratigraphic correlations with Early Jurassic sections in Alberta containing ammonite biostratigraphy, $\mathrm{Re}-\mathrm{Os}$ (ORM) and $\mathrm{U}-\mathrm{Pb}$ (bentonite) ages constrain the age of the Toarcian N-CIE in the core to between 185 and $182 \mathrm{Ma}$ (see SI).

Local bottom water redox conditions during deposition of the Gordondale Member in our study section can be constrained using redox-sensitive metals like uranium and vanadium. Like Re and Mo, these metals are soluble in oxygenated seawater and have low burial rates into oxygenated sediments ${ }^{36}$. Both Mo and $V$ require bottom water euxinia for large authigenic enrichments ( $X_{\text {auth }}$; Equation $\left.S 1\right)$ in sediments, whereas Re and $U$ do not ${ }^{37-44}$. Thus, low or mild $V_{\text {auth }}$ and $\mathrm{Mo}_{\text {auth }}$ enrichments but elevated $U_{\text {auth }}(>10 \mu \mathrm{g} / \mathrm{g})^{43}$ and $\operatorname{Re}_{\text {auth }}(>42 \mathrm{ng} / \mathrm{g})^{40}$ enrichments in sediments suggest deposition from locally ferruginous bottom waters. Elevated enrichment of all four metals (with $\mathrm{V}_{\text {auth }}>320-500 \mu \mathrm{g} / \mathrm{g} ; \mathrm{Mo}_{\text {auth }}>$ $100 \mu \mathrm{g} / \mathrm{g})^{39,42,44}$ suggests deposition from locally euxinic bottom waters. Sediments deposited from euxinic bottom-waters have lower Re/ $\mathrm{Mo}_{\text {auth }}(<4)^{45}$ and $\mathrm{U} / \mathrm{Mo}_{\text {auth }}(<0.13)^{40,45-47}$ ratios whereas higher ratios are expected in sediments deposited from ferruginous $\left(\mathrm{Re} / \mathrm{Mo}_{\text {auth }}=4-10\right)^{40,45}$ or suboxic $\left(\mathrm{Re} / \mathrm{Mo}_{\text {auth }}>10\right)^{40,45}$ bottom-waters.

The Gordondale Member hosts elevated $\operatorname{Re}_{\text {auth }}\left(207 \pm 91 \mathrm{ng} / \mathrm{g}, 1 \mathrm{s.d}\right.$.) and $\mathrm{U}_{\text {auth }}(13 \pm 8 \mu \mathrm{g} / \mathrm{g}, 1 \mathrm{s.d}$.), like many Phanerozoic ORM deposited from anoxic bottom waters ${ }^{24,43}$. By contrast, $\mathrm{V}_{\text {auth }}(764 \pm 568 \mu \mathrm{g} / \mathrm{g}, 1$ s.d.), $\mathrm{Mo}_{\text {auth }}\left(96 \pm 88 \mu \mathrm{g} / \mathrm{g}, 1\right.$ s.d.), $\mathrm{Re} / \mathrm{Mo}_{\text {auth }}\left(4.7 \pm 4.4,1\right.$ s.d.) and $\mathrm{U} / \mathrm{Mo}_{\text {auth }}(0.30 \pm 0.36,1$ s.d.) are variable. The divergence between anoxic $\left(\mathrm{U}_{\text {auth }}, \mathrm{Re} \mathrm{euth}_{\text {auth }}\right)$ and euxinic $\left(\mathrm{Mo}_{\text {auth }}, \mathrm{V}_{\text {auth }}, \mathrm{Re} / \mathrm{Mo}_{\text {auth }}, \mathrm{U} / \mathrm{Mo}_{\text {auth }}\right)$ indicators reveals that deposition occurred under both ferruginous and euxinic bottom water conditions, and rarely under suboxic conditions. Large variance $(> \pm 70 \%$ of the mean) remains when comparing the euxinic indicators in the Pre N-CIE and N-CIE intervals. Hence, we further subdivide the Gordondale Member into Lower Pre N-CIE (euxinic), Upper Pre N-CIE (ferruginous), Lower N-CIE (ferruginous) and Upper N-CIE (euxinic) intervals. The greatest enrichments occur in the Lower Pre $N-C I E\left(\operatorname{Re}_{\text {auth }}=215 \pm 88\right.$ $\mathrm{ng} / \mathrm{g} ; \mathrm{Mo}_{\text {auth }}=168 \pm 91 \mu \mathrm{g} / \mathrm{g} ; 1$ s.d. $)$ and Upper N-CIE $\left(\mathrm{Re}_{\text {auth }}=277 \pm 74 \mathrm{ng} / \mathrm{g} ; \mathrm{Mo}_{\text {auth }}=108 \pm 22 \mu \mathrm{g} / \mathrm{g} ; 1\right.$ 
s.d.) intervals and the smallest enrichments occur in the Upper Pre $N-C I E\left(\operatorname{Re}_{\text {auth }}=125 \pm 68 \mathrm{ng} / \mathrm{g}\right.$; $\mathrm{Mo}_{\text {auth }}$ $=23 \pm 11 \mu \mathrm{g} / \mathrm{g} ; 1$ s.d. $)$ and Lower N-CIE $\left(\mathrm{Re}_{\text {auth }}=192 \pm 95 \mathrm{ng} / \mathrm{g} ; \mathrm{Mo}_{\text {auth }}=33 \pm 18 \mu \mathrm{g} / \mathrm{g} ; 1 \mathrm{~s}\right.$.d. $)$ intervals. Samples that were likely deposited under suboxic conditions $\left(\mathrm{Re} / \mathrm{Mo}_{\text {auth }}>10\right)$ were not included in the mean calculations. The low $\mathrm{Mo}_{\text {auth }}$ in the Upper Pre N-CIE and Lower $\mathrm{N}-\mathrm{CIE}$ is probably not due to an expansion of global euxinia drawing down the oceanic Mo reservoir ${ }^{18}$ because $\operatorname{Re}_{\text {auth }}\left(\right.$ and $U_{\text {auth }}$ ) should show a similar drawdown, which is not observed. Instead, the decline in $\mathrm{Mo}_{\text {auth }}$ and increased $\mathrm{U} / \mathrm{Mo}_{\text {auth }}$ and $\mathrm{Re} / \mathrm{Mo}_{\text {auth }}$ in the middle portion of the core are interpreted as a transition from euxinic to ferruginous anoxia in the local depositional environment.

Covariations of Mo versus $\mathrm{U}$ and cadmium versus Mo can be used to determine paleohydrographic conditions during deposition of the Gordondale Member ${ }^{47,48}$ (see discussion in $\mathrm{SI}$ ). The Mo-U covariation trend for the Gordondale ORM suggests vigorous water-mass exchange with the open ocean ${ }^{47}$. The $\mathrm{Cd}-$ Mo covariation corroborates this interpretation, and the elevated $\mathrm{Cd}$ content further suggests an environment where upwelling of deep-water nutrients enhanced primary productivity ${ }^{48}$. Based on the local hydrographic regime and its deposition from ferruginous or euxinic bottom waters, the Gordondale Member core is ideal for estimating global ocean redox conditions from redox-sensitive metal concentrations.

\section{Mass Balance Modeling of Global Seafloor Total Anoxia and Euxinia}

First-order approximations of global anoxic and euxinic seafloor area can be inferred from $\mathrm{Re}_{\text {auth }}$ and $\mathrm{Mo}_{\text {auth }}$ enrichments in ORM deposited in areas well-connected to global ocean circulation ${ }^{18,24}$. Modern seawater Re and Mo concentrations are regulated primarily by rivers with minor seafloor hydrothermal inputs ${ }^{25}$, and burial into sediments deposited from oxic, suboxic, and anoxic (Re) or euxinic (Mo) bottom waters ${ }^{18,24}$. Rhenium is removed most efficiently to the anoxic sink as indicated by an average burial rate of $1.3 \mathrm{ng} / \mathrm{cm}^{2} \mathrm{yr}$, which is one to three orders of magnitude greater than suboxic $\left(4.2 \times 10^{-1} \mathrm{ng} / \mathrm{cm}^{2} \mathrm{yr}\right)$ and oxic $\left(1.6 \times 10^{-3} \mathrm{ng} / \mathrm{cm}^{2} \mathrm{yr}\right)$ settings ${ }^{24}$. Burial rates of Re into sediments beneath ferruginous and euxinic bottom waters are not significantly different because Re removal to organic-rich sediments depends on $\mathrm{O}_{2}$ deficiency rather than $\mathrm{H}_{2} \mathrm{~S}$ availability ${ }^{24,40}$. In contrast, Mo removal to these sediments hinges on the presence of free $\mathrm{H}_{2} \mathrm{~S}$ in bottom waters ${ }^{42}$ such that there is a large offset between average Mo burial rates in oxic $\left(2.75 \times 10^{-3} \mu \mathrm{g} / \mathrm{cm}^{2} \mathrm{yr}\right)$ and suboxic $\left(0.27 \mu \mathrm{g} / \mathrm{cm}^{2} \mathrm{yr}\right)$ versus euxinic $(1.53$ $\mu \mathrm{g} / \mathrm{cm}^{2} \mathrm{yr}$ ) sediments ${ }^{18}$. The high Re and Mo burial rates in anoxic and euxinic settings, respectively, means that a relatively minor expansion of anoxic or euxinic seafloor will result in substantial drawdown of these metals from seawater until a new steady state is reached. A smaller oceanic metal reservoir should lead to lower enrichments in marine ORM deposited from locally ferruginous or euxinic waters. Hence, Re and Mo enrichments in ORM, coupled with a recently developed mass balance model ${ }^{24}$ (Equations S2-S5) can be used to track changes in the extent of global ocean anoxia and euxinia associated with the T-OAE. 
Application of the mass balance model to data from the Gordondale Member before and during the TOAE requires samples selected from locally anoxic $(\mathrm{Re})$ or euxinic (Mo) ORM ${ }^{18,24}$. Thus, the euxinic seafloor area from the Mo mass balance is not calculated for the locally non-euxinic Upper Pre N-CIE and Lower N-CIE intervals, but the anoxic seafloor area can be deduced from all four defined Gordondale Member intervals. To produce a representative model of the change in global anoxic and euxinic seafloor area before and during the $\mathrm{T}-\mathrm{OAE}$, local spatiotemporal parameters were applied to these stratigraphic intervals. We assess the impact on mass-balance model solutions by local bulk sediment mass accumulation rate (Equation S6), thermal maturity (Equation S7), and Early Jurassic Re and Mo input fluxes from rivers and hydrothermal sources. We present an environmentally realistic scenario, with further sensitivity analysis described in the SI.

The modern Re and Mo riverine fluxes to the oceans are $4.29 \times 10^{5} \mathrm{~mol} / \mathrm{yr}$ and $3.00 \times 10^{8} \mathrm{~mol} / \mathrm{yr}$, respectively 24,25 , which is the assumed baseline (pre N-CIE) flux given broadly similar atmospheric $\mathrm{O}_{2}$ levels at that time compared to modern ${ }^{49}$. Riverine fluxes scale with the rate of continental weathering, which is estimated to have increased by $215-530 \%$ over a $100-200$ kyr period at the onset of the T-OAE based on Os and Ca isotope data ${ }^{10,11}$. The Os isotope data is from the Red Deer Member ${ }^{10}$, which is closely related to the Gordondale Member in the c-B6-A/94-B-8 core, however, a sill between the units may have created minor basin restriction during Red Deer Member deposition ${ }^{50}$. The c-B6-A/94-B-8 core contains consistently elevated authigenic $\operatorname{Re}(208 \pm 91 \mathrm{ng} / \mathrm{g}$, 1 s.d.) and total organic carbon (TOC) content $(6.4 \pm 2.2 \%, 1$ s.d.), while the East Tributary section hosting the Red Deer Member contains variably low Re concentrations $(52 \pm 49 \mathrm{ng} / \mathrm{g}, 1 \text { s.d. })^{10}$ and moderate TOC content $(3.9 \pm 1.0 \%, 1 \text { s.d.) })^{27}$. The lower Re contents at East Tributary is not a result of more oxygenated conditions because sedimentary Fe speciation data indicates deposition from locally euxinic bottom waters ${ }^{51}$. Hence, the minor hydrographic restriction at the Red Deer Member depositional locality could have caused local seawater ${ }^{187} \mathrm{Os} /{ }^{188} \mathrm{Os}$ to be higher than global seawater such that the weathering rate evaluation (215$530 \%$ increase) from the East Tributary section ${ }^{10}$ may be a mild overestimation. Hence, we apply a conservative threefold increase of Re and Mo riverine flux at the onset of the $\mathrm{N}-\mathrm{CIE}$ and maintain this flux through both Lower and Upper N-CIE intervals.

Hydrothermal Re and Mo fluxes to modern seawater are poorly constrained but are likely minor compared to riverine flux ${ }^{24,25}$. Sensitivity analyses of hydrothermal fluxes demonstrate that its subordinate contribution compared to river flux obviate its impact on the Re and Mo mass balance (see SI), thus the hydrothermal flux was excluded from the mass-balance model.

\section{Maximum Extent of Anoxia at the Onset of the T-OAE}

The Re model yields the proportion of total seafloor area covered by anoxic sediments ( $\left.A_{\text {anoxic }}\right)$. The results fall within a narrow range for the Lower Pre N-CIE (0.14-2.5\%), Upper Pre N-CIE (1.1-8.2\%) and Upper N-CIE (2.9-6.4\%) intervals (Figure 3A,B). The Lower N-CIE interval has the greatest uncertainty in $A_{\text {anoxic }}(3.9-100 \%)$ due to the asymptotic nature of the model when $A_{\text {anoxic }}$ is less than $1 \%$ or greater than 
$10 \%$ total seafloor area. Variation in $\mathrm{A}_{\text {anoxic }}$ is rooted in the $\mathrm{Re}_{\text {auth }}$ variance for each interval, which likely reflects, at least in part, changes in local depositional conditions such as fluctuating redox conditions, host phase availability/composition or sedimentation rates ${ }^{52}$, rather than global redox changes. It is important to note that lower Re concentrations, caused by local depositional factors, do not actually convey meaningful information about the global extent of ocean anoxia. Hence, mean Re concentrations are a more robust global redox indicator and were used to calculate mean anoxic seafloor areas of $0.84 \%$, $2.6 \%, 6.9 \%$ and $4.1 \%$ of the global seafloor area for the respective stratigraphic intervals. These estimates may reflect maximum constraints for the extent of seafloor anoxia because Re concentrations higher than the means suggest lower extents of seafloor anoxia.

The areas of euxinic seafloor from the Mo mass balance model ( $A_{\text {euxinic }}$ ) also fall within a narrow range for the Lower Pre N-CIE (0.15-1.4\%) and Upper N-CIE (3.9-6.2\%) intervals and are independently stratigraphically consistent with $A_{\text {anoxic }}$ (Figure $3 C, D$ ). Mean $A_{\text {euxinic }}$ estimates are $0.47 \%$ and $4.8 \%$ for the Lower Pre N-CIE and Upper N-CIE intervals, respectively. As a subclass of anoxia, euxinia should cover a seafloor area equal to or less than total seafloor anoxia. The range of $A_{\text {euxinic }}$ falls within the range of $A_{\text {anoxic }}$ for both Lower Pre N-CIE and Upper N-CIE intervals, and the mean $A_{\text {euxinic }}$ for both intervals is not appreciably different considering model uncertainties ( $p$-values $>0.16$ for paired t-tests).

The Re mass balance model yields a maximum area of seafloor anoxia at the onset of the N-CIE and a contraction of anoxic seafloor area towards the conclusion of the N-CIE. An areal decrease of globally anoxic bottom waters through the T-OAE is consistent with other global redox reconstructions from Europe and Canada ${ }^{16,51}$. The Pre N-CIE interval exhibits global ocean redox conditions similar to modern, however, a minor expansion of seafloor anoxia directly preceding the N-CIE suggests that the T-OAE began prior to the classically recognized $\delta^{13} \mathrm{C}$ expression of the event. A similar observation was noted in the $\mathrm{Tl}$ isotope record from another Canadian T-OAE section ${ }^{51}$. This early expansion was not documented in global redox reconstructions from Europe because pre-N-CIE bottom water conditions recorded in those sections are thought to have been generally oxic ${ }^{15,16}$.

Combining the findings from the Re and Mo models illuminates the redox structure of the global ocean before and during the T-OAE. The offset between mean $\mathrm{A}_{\text {anoxic }}$ and $\mathrm{A}_{\text {euxinic }}$ in the Lower Pre N-CIE and Upper $\mathrm{N}$-CIE intervals are not statistically different, suggesting euxinic rather than ferruginous conditions covered most of the anoxic seafloor, as observed in modern anoxic environments.

The increase in seafloor area covered by euxinic conditions likely played a role in the extinctions that occurred during the T-OAE. Several studies have invoked anoxia, and specifically sulfidic anoxia, as a likely kill mechanism for marine fauna during other mass extinctions ${ }^{53-55}$. The modern continental shelf and slope where biota is most heavily concentrated account for $3.6 \%$ and $5.6 \%$ of the global ocean area, respectively, totalling $9.2 \%{ }^{56}$. If the area of Toarcian continental shelf and slope were not substantially different from the present, then our model suggests that the maximum expansion of anoxia (primarily as euxinia) in the early portion of the T-OAE did not extend into the deep ocean but remained within the 
continental margins (e.g., Panthalassa ocean margins) ${ }^{27,30-33}$ or epicontinental seas (e.g., Tethys sea sub-basins) ${ }^{15-17,19-21,28,29}$. The Re mass-balance model results suggest that the open deep oceans away from continental margins likely remained predominantly oxygenated during the T-OAE, although potentially below modern levels ${ }^{57}$, contrasting with past statements suggesting "widespread" anoxia ${ }^{1,15}$. Our results align with estimates from previous Mo isotope studies which suggested euxinia covered < $10 \%$ of the global seafloor ${ }^{16,17}$. Our novel approach of using Re and Mo mass-balance models to independently estimate the total anoxic seafloor and euxinic seafloor areas show that even modest expansions of anoxia expressed as euxinia can be associated with catastrophic marine die-offs, as reported for the Toarcian².

Our approach towards inferring global ocean redox conditions may be applicable to other intervals of the Phanerozoic characterized by severe mass extinctions, or in forecasting changes to the modern world. The modern Earth is likely experiencing dramatic surface changes such as an enhanced greenhouse atmosphere spurred by industrial, rather than volcanic, activity. The resulting environmental feedbacks associated with the accumulation of anthropogenic greenhouse gases is leading to species loss akin to those of past climate events ${ }^{58}$. Application of the coupled Re-Mo paleoredox proxy may improve understanding of the magnitude of ocean redox changes during ancient expansions of oceanic anoxia and euxinia and their effects on biodiversity, and thus may enable prediction of the results of human impacts on the biosphere. The coupled Re-Mo paleoredox proxy may also help track longer-term changes in the distribution of euxinic versus ferruginous seafloor throughout the Phanerozoic Eon.

\section{Methods}

Trace Metals. Sample preparation and analysis for trace metal content was performed at the Metal Isotope Geochemistry Laboratory, University of Waterloo. Samples without secondary features (e.g., fossils, veins, macroscopic pyrite nodules) were chosen for analysis. Samples were crushed without metal contact and powdered in a Retsch ball mill with agate grinding jars. Approximately $100 \mathrm{mg}$ of powder was ashed overnight at $550^{\circ} \mathrm{C}$ to oxidize organic matter. Ashed powders were digested at $110^{\circ} \mathrm{C}$ in $2.5 \mathrm{ml}$ concentrated $\mathrm{HNO}_{3}$ and $0.5 \mathrm{ml}$ concentrated $\mathrm{HF}$ for $48 \mathrm{~h}$, followed by digestion in $4 \mathrm{ml}$ aqua regia for $48 \mathrm{~h}$ and finally in $2 \mathrm{ml}$ concentrated $\mathrm{HCl}$ for $24 \mathrm{~h}$. Digested solutions were diluted 400 -fold for $\mathrm{Re}$ and $\mathrm{Cd}$, and 6000 -fold for other elements by $2 \% \mathrm{HNO}_{3}$ and trace $\mathrm{HF}$ was added to ensure sample stability. Elemental concentrations were measured on an Agilent 8800 triple-quadrupole inductively coupled plasma mass spectrometer calibrated against standard solutions containing metal concentrations designed to be similar to the matrix of ORM. Internal standards Sc, Ge, In and Bi were used to correct for instrument drift. Instrument accuracy was verified by analyzing United States Geological Survey ORM standards SBC- $1^{59}$ and SGR-1 $b^{60}$ multiple times during each analytical session to ensure accuracy. Concentration reproducibility was typically better than $5 \%$.

Organic Carbon Isotopes. Organic C isotope analysis was performed at the Environmental Isotope Laboratory, University of Waterloo. Sample powders were subjected to two rounds of $10 \% \mathrm{HCl}$ 
acidification at $50^{\circ} \mathrm{C}$ to leach carbonate, followed by rinsing with NanoPure water to remove excess acid. Approximately 1-10 mg of leached powder was placed in a foil cup for analysis on a Costech Instruments 4010 Elemental Analyzer coupled to a Thermo-Finnigan Delta Plus XL continuous-flow isotope ratio mass spectrometer. Carbon isotope ratios are reported against international and in-house standard reference materials calibrated to PeeDee Belemnite. Analytical precision was $\pm 0.2 \%$.

\section{Declarations}

\section{Acknowledgements}

Sample collection and analyses were funded by a Mitacs Accelerate grant, NSERC Discovery Grants (RGPIN-2013-435930/RGPIN-2019-04090), and the Canada Research Chairs program. The Metal Isotope Geochemistry Laboratory was funded by the Canada Foundation for Innovation, Ontario Research Fund, and University of Waterloo.

\section{Author Contributions}

The study was developed by A.K. and B.K. Analysis and data processing were carried out by A.K. Preparation of the manuscript was undertaken by A.K., with input from B.K.

\section{Competing Interests}

None to declare.

\section{References}

1. Pálfy, J. \& Smith, P. L. Synchrony between Early Jurassic extinction, oceanic anoxic event, and the Karoo-Ferrar flood basalt volcanism. Geology 28, 747-750 (2000).

2. Caruthers, A. H., Smith, P. L. \& Gröcke, D. R. The Pliensbachian-Toarcian (Early Jurassic) extinction, a global multi-phased event. Palaeogeography, Palaeoclimatology, Palaeoecology 386, 104-118 (2013).

3. Ikeda, M. \& Hori, R. S. Effects of Karoo-Ferrar volcanism and astronomical cycles on the Toarcian Oceanic Anoxic Events (Early Jurassic). Palaeogeography, Palaeoclimatology, Palaeoecology 410, 134-142 (2014).

4. Boulila, S. et al. Astronomical calibration of the Toarcian Stage: Implications for sequence stratigraphy and duration of the early Toarcian OAE. Earth and Planetary Science Letters 386, 98111 (2014).

5. Sell, B. et al. Evaluating the temporal link between the Karoo LIP and climatic-biologic events of the Toarcian Stage with high-precision U-Pb geochronology. Earth and Planetary Science Letters 408, 48-56 (2014). 
6. Burgess, S. D., Bowring, S. A., Fleming, T. H. \& Elliot, D. H. High-precision geochronology links the Ferrar large igneous province with early-Jurassic ocean anoxia and biotic crisis. Earth and Planetary Science Letters 415, 90-99 (2015).

7. Ruebsam, W., Reolid, M., Sabatino, N., Masetti, D. \& Schwark, L. Molecular paleothermometry of the early Toarcian climate perturbation. Global and Planetary Change 195, 103351 (2020).

8. Hermoso, M., Minoletti, F. \& Pellenard, P. Black shale deposition during Toarcian super-greenhouse driven by sea level. Climate of the Past 9, 2703-2712 (2013).

9. Bailey, T. R., Rosenthal, Y., McArthur, J. M., van de Schootbrugge, B. \& Thirlwall, M. F. Paleoceanographic changes of the Late Pliensbachian-Early Toarcian interval: a possible link to the genesis of an Oceanic Anoxic Event. Earth and Planetary Science Letters 212, 307-320 (2003).

10. Them, T. R. et al. Evidence for rapid weathering response to climatic warming during the Toarcian Oceanic Anoxic Event. Scientific Reports 7, (2017).

11. Brazier, J. M. et al. Calcium isotope evidence for dramatic increase of continental weathering during the Toarcian oceanic anoxic event (Early Jurassic). Earth and Planetary Science Letters 411, 164176 (2015).

12. Jenkyns, H. C. The Early Toarcian (Jurassic) Anoxic Event: Stratigraphic, Sedimentary, and Geochemical Evidence. American Journal of Science 288, 101-151 (1988).

13. Jenkyns, H. C. Geochemistry of oceanic anoxic events. Geochemistry, Geophysics, Geosystems 11, (2010).

14. Tyson, R. v. \& Pearson, T. H. Modern and ancient continental shelf anoxia: an overview. Geological Society, London, Special Publications 58, 1-24 (1991).

15. Pearce, C. R., Cohen, A. S., Coe, A. L. \& Burton, K. W. Molybdenum isotope evidence for global ocean anoxia coupled with perturbations to the carbon cycle during the early Jurassic. Geology 36, 231234 (2008).

16. Dickson, A. J. et al. Molybdenum-isotope chemostratigraphy and paleoceanography of the Toarcian Oceanic Anoxic Event (Early Jurassic). Paleoceanography 32, 813-829 (2017).

17. Dickson, A. J. A molybdenum-isotope perspective on Phanerozoic deoxygenation events. Nature Geoscience 10, 721-726 (2017).

18. Reinhard, C. T. et al. Proterozoic ocean redox and biogeochemical stasis. Proceedings of the National Academy of Sciences 110, 5357-5362 (2013).

19. McArthur, J. M., Algeo, T. J., van de Schootbrugge, B., Li, Q. \& Howarth, R. J. Basinal restriction, black shales, Re-Os dating, and the Early Toarcian (Jurassic) oceanic anoxic event. Paleoceanography 23, (2008).

20. McArthur, J. M. Early Toarcian black shales: A response to an oceanic anoxic event or anoxia in marginal basins? Chemical Geology 522, 71-83 (2019).

21. Rodríguez-Tovar, F. J. \& Reolid, M. Environmental conditions during the Toarcian Oceanic Anoxic Event (T-OAE) in the westernmost Tethys: influence of the regional context on a global phenomenon. 
Bulletin of Geosciences 88, 697-712 (2013).

22. Kendall, B., Dahl, T. W. \& Anbar, A. D. The Stable Isotope Geochemistry of Molybdenum. Reviews in Mineralogy and Geochemistry 82, 683-732 (2017).

23. Them, T. R. et al. Thallium isotopes reveal protracted anoxia during the Toarcian (Early Jurassic) associated with volcanism, carbon burial, and mass extinction. Proceedings of the National Academy of Sciences of the United States of America 115, 6596-6601 (2018).

24. Sheen, A. I. et al. A model for the oceanic mass balance of rhenium and implications for the extent of Proterozoic ocean anoxia. Geochimica et Cosmochimica Acta 227, 75-95 (2018).

25. Miller, C. A., Peucker-Ehrenbrink, B., Walker, B. D. \& Marcantonio, F. Re-assessing the surface cycling of molybdenum and rhenium. Geochimica et Cosmochimica Acta 75, 7146-7179 (2011).

26. Morford, J. L., Martin, W. R. \& Carney, C. M. Rhenium geochemical cycling: Insights from continental margins. Chemical Geology 324-325, 73-86 (2012).

27. Them, T. R. et al. High-resolution carbon isotope records of the Toarcian Oceanic Anoxic Event (Early Jurassic) from North America and implications for the global drivers of the Toarcian carbon cycle. Earth and Planetary Science Letters 459, 118-126 (2017).

28. Schouten, S. et al. Effects of an Oceanic Anoxic Event on the Stable Carbon Isotopic Composition of Early Toarcian Carbon. American Journal of Science 300, 1-22 (2000).

29. Hesselbo, S. P. et al. Massive dissociation of gas hydrate during a Jurassic oceanic anoxic event. Nature 2000 406:6794 406, 392-395 (2000).

30. Al-Suwaidi, A. H. et al. First record of the Early Toarcian Oceanic Anoxic Event from the Southern Hemisphere, Neuquén Basin, Argentina. Journal of the Geological Society 167, 633-636 (2010).

31. Caruthers, A. H., Gröcke, D. R. \& Smith, P. L. The significance of an Early Jurassic (Toarcian) carbonisotope excursion in Haida Gwaii (Queen Charlotte Islands), British Columbia, Canada. Earth and Planetary Science Letters 307, 19-26 (2011).

32. Gröcke, D. R., Hori, R. S., Trabucho-Alexandre, J., Kemp, D. B. \& Schwark, L. An open ocean record of the Toarcian oceanic anoxic event. Solid Earth 2, 245-257 (2011).

33. Fantasia, A. et al. The Toarcian Oceanic Anoxic Event in southwestern Gondwana: an example from the Andean Basin, northern Chile. Journal of the Geological Society 175, 883-902 (2018).

34. Them, T. R. et al. Terrestrial sources as the primary delivery mechanism of mercury to the oceans across the Toarcian Oceanic Anoxic Event (Early Jurassic). Earth and Planetary Science Letters 507, 62-72 (2019).

35. van de Schootbrugge, B. et al. Early Jurassic climate change and the radiation of organic-walled phytoplankton in the Tethys Ocean. Paleobiology 31, 73-97 (2005).

36. Tribovillard, N., Algeo, T. J., Lyons, T. \& Riboulleau, A. Trace metals as paleoredox and paleoproductivity proxies: An update. Chemical Geology 232, 12-32 (2006).

37. Breit, G. N. \& Wanty, R. B. Vanadium accumulation in carbonaceous rocks: A review of geochemical controls during deposition and diagenesis. Chemical Geology 91, 83-97 (1991). 
38. Klinkhammer, G. P. \& Palmer, M. R. Uranium in the oceans: Where it goes and why. Geochimica et Cosmochimica Acta 55, 1799-1806 (1991).

39. Quinby-Hunt, M. S. \& Wilde, P. Thermodynamic zonation in the black shale facies based on ironmanganese-vanadium content. Chemical Geology 113, 297-317 (1994).

40. Crusius, J., Calvert, S., Pedersen, T. \& Sage, D. Rhenium and molybdenum enrichments in sediments as indicators of oxic, suboxic and sulfidic conditions of deposition. Earth and Planetary Science Letters 145, 65-78 (1996).

41. McManus, J., Berelson, W. M., Klinkhammer, G. P., Hammond, D. E. \& Holm, C. Authigenic uranium: Relationship to oxygen penetration depth and organic carbon rain. Geochimica et Cosmochimica Acta 69, 95-108 (2005).

42. Scott, C. \& Lyons, T. W. Contrasting molybdenum cycling and isotopic properties in euxinic versus non-euxinic sediments and sedimentary rocks: Refining the paleoproxies. Chemical Geology 324325, 19-27 (2012).

43. Partin, C. A. et al. Large-scale fluctuations in Precambrian atmospheric and oceanic oxygen levels from the record of $U$ in shales. Earth and Planetary Science Letters 369-370, 284-293 (2013).

44. Kunert, A., Clarke, J. \& Kendall, B. Molybdenum isotope constraints on the origin of vanadium hyperenrichments in ediacaran- phanerozoic marine mudrocks. Minerals 10, (2020).

45. Turgeon, S. \& Brumsack, H. J. Anoxic vs dysoxic events reflected in sediment geochemistry during the Cenomanian-Turonian Boundary Event (Cretaceous) in the Umbria-Marche Basin of central Italy. Chemical Geology 234, 321-339 (2006).

46. Zhou, L. et al. U/Mo ratios and $\delta 98 / 95 \mathrm{Mo}$ as local and global redox proxies during mass extinction events. Chemical Geology 324-325, 99-107 (2012).

47. Algeo, T. J. \& Tribovillard, N. Environmental analysis of paleoceanographic systems based on molybdenum-uranium covariation. Chemical Geology 268, 211-225 (2009).

48. Sweere, T., van den Boorn, S., Dickson, A. J. \& Reichart, G. J. Definition of new trace-metal proxies for the controls on organic matter enrichment in marine sediments based on Mn, Co, Mo and Cd concentrations. Chemical Geology 441, 235-245 (2016).

49. Krause, A. J. et al. Stepwise oxygenation of the Paleozoic atmosphere. Nature Communications $\mathbf{9}$, (2018).

50. Gordey, S. P. et al. Upper Devonian to Middle Jurassic assemblages Part A: Ancestral North America. in Geology of the Cordilleran Orogen in Canada (eds. Gabrielse, H. \& Yorath, C. J.) vol. 4 219-327 (Geological Survey of Canada, Geology of Canada, 1991).

51. Them, T. R. et al. Thallium isotopes reveal protracted anoxia during the Toarcian (Early Jurassic) associated with volcanism, carbon burial, and mass extinction. Proceedings of the National Academy of Sciences 115, 6596-6601 (2018).

52. Algeo, T. J. \& Rowe, H. Paleoceanographic applications of trace-metal concentration data. Chemical Geology 324-325, 6-18 (2012). 
53. Zou, C. et al. Ocean euxinia and climate change "double whammy" drove the Late Ordovician mass extinction. Geology 46, 535-538 (2018).

54. Meyer, K. M., Kump, L. R. \& Ridgwell, A. Biogeochemical controls on photic-zone euxinia during the end-Permian mass extinction. Geology 36, 747-750 (2008).

55. Grice, K. et al. Photic Zone Euxinia During the Permian-Triassic Superanoxic Event. Science 307, 706-709 (2005).

56. Drake, C. L. \& Burk, C. A. Geological Significance of Continental Margins. in The Geology of Continental Margins 3-10 (Springer-Verlag, 1974).

57. Stolper, D. A. \& Keller, C. B. A record of deep-ocean dissolved 02 from the oxidation state of iron in submarine basalts. Nature 2018 553:7688 553, 323-327 (2018).

58. Ceballos, G. et al. Accelerated modern human-induced species losses: Entering the sixth mass extinction. doi:10.1126/sciadv.1400253.

59. Li, J. \& Yin, L. Rhenium-Osmium Isotope Measurements in Marine Shale Reference Material SBC-1: Implications for Method Validation and Quality Control. Geostandards and Geoanalytical Research 43, 497-507 (2019).

60. Yin, L. et al. Precise and accurate Re-Os isotope dating of organic-rich sedimentary rocks by thermal ionization mass spectrometry with an improved $\mathrm{H} 2 \mathrm{O} 2-\mathrm{HNO} 3$ digestion procedure. International Journal of Mass Spectrometry 421, 263-270 (2017).

61. Scotese, C. Map Folio 39 Early Jurassic Toarcian, 179.3 Ma. (2013).

\section{Figures}

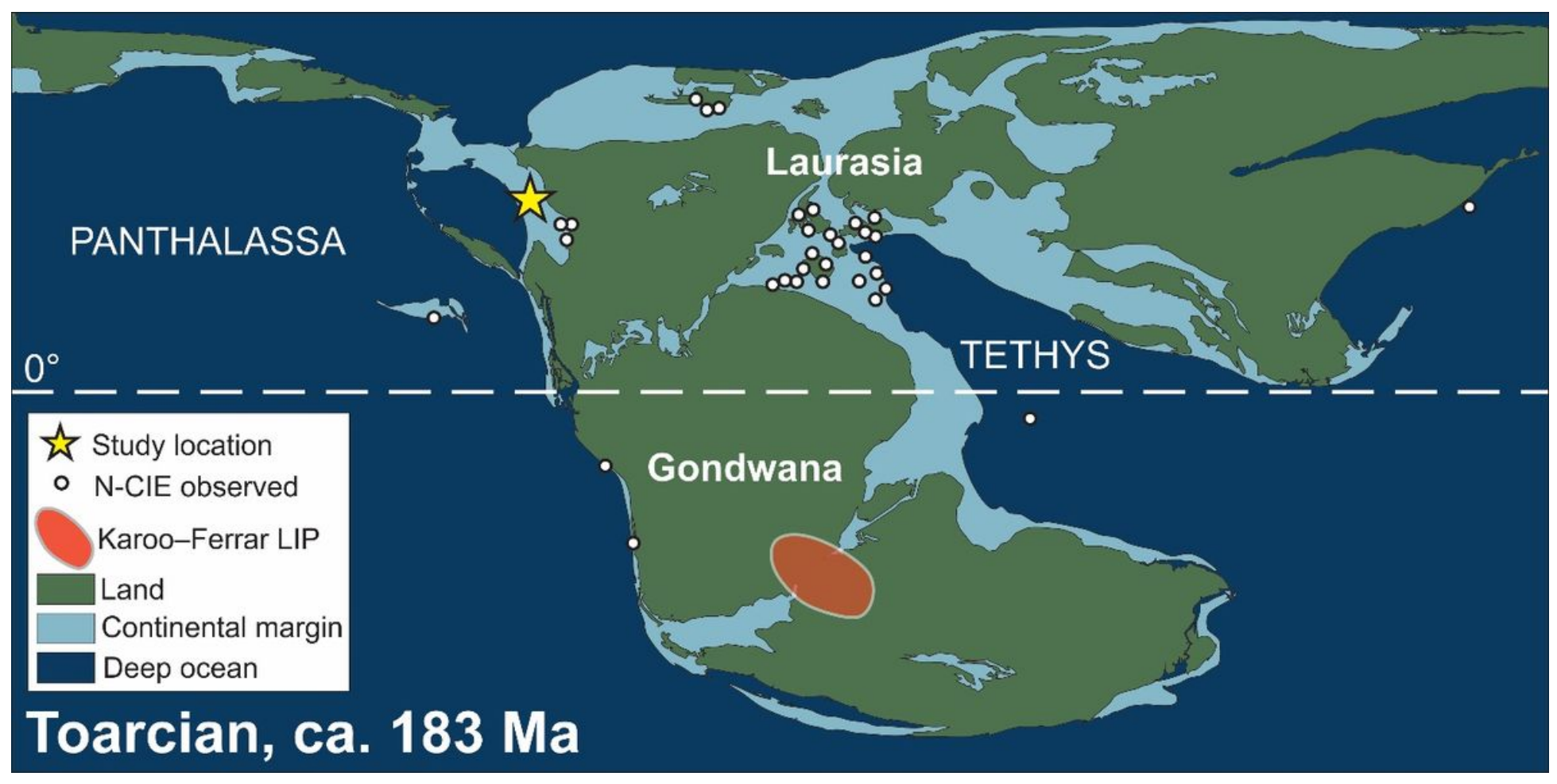


Global Toarcian paleogeography. Negative carbon isotope excursion locations ${ }^{27}$ used to identify the Toarcian Oceanic Anoxic Event are shown. The core used in this study was deposited along the western margin of Laurasia (proto-North America), and was connected to the Panthalassa ocean. Figure modified from Scotese ${ }^{61}$.

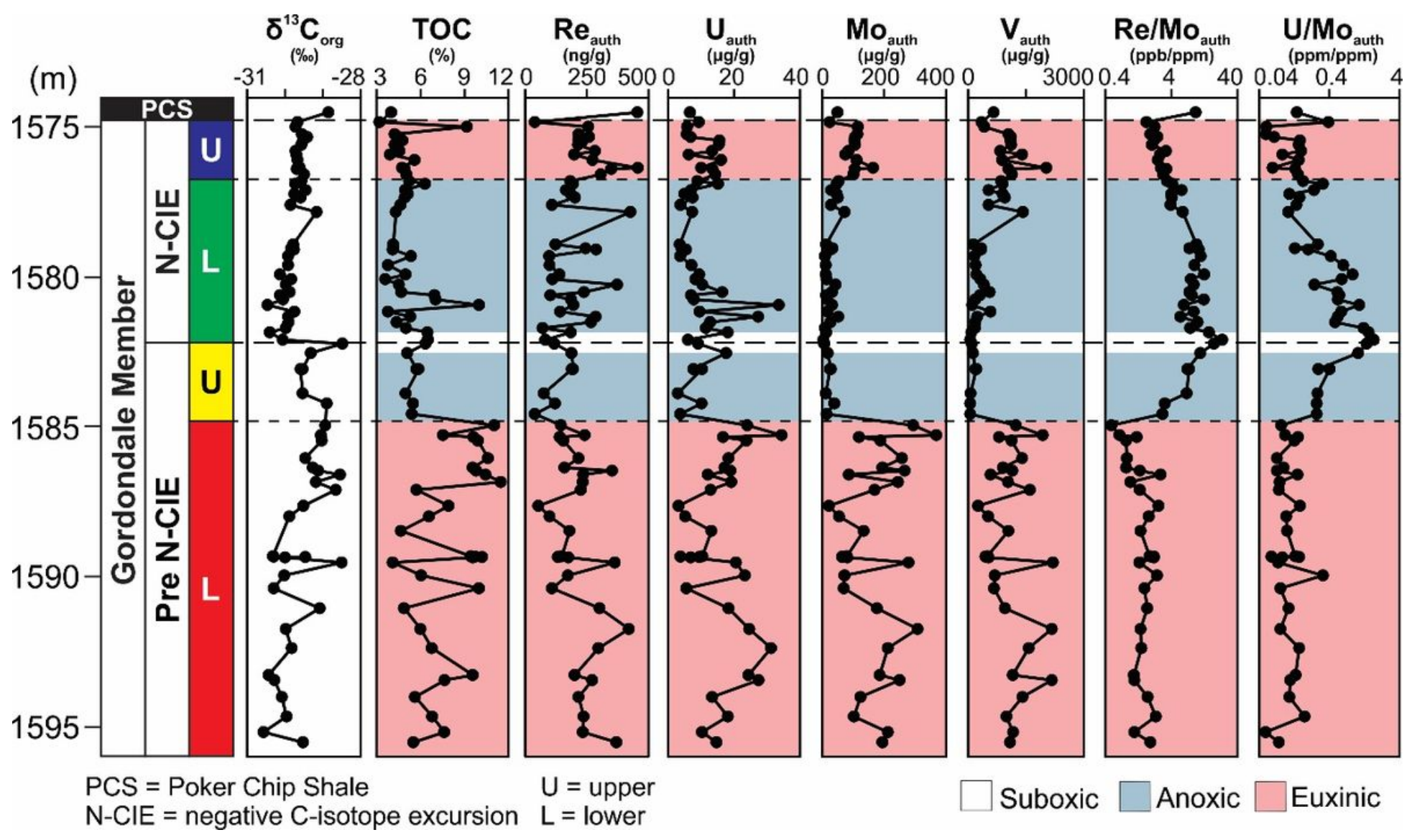

Figure 2

Gordondale Member core geochemical profiles. The Toarcian Oceanic Anoxic Event (T-OAE) is classically recognized by a negative carbon isotope excursion ( $\mathrm{N}-\mathrm{CIE})$, which is observed in the organic carbon fraction $\left(\delta^{13} \mathrm{C}_{\text {org }}\right)$ between 1575.00 and $1582.10 \mathrm{~m}$ depth. 

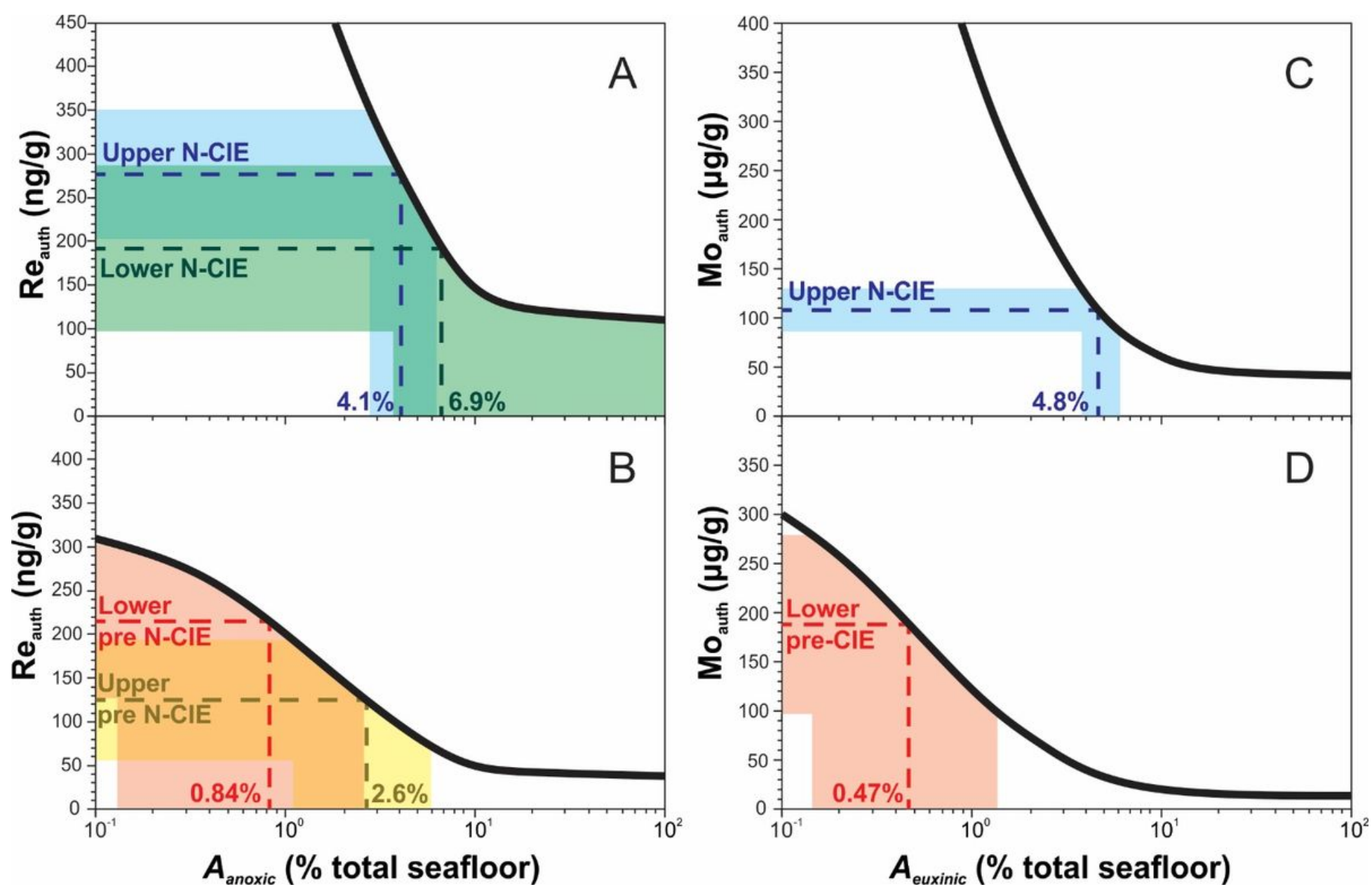

\section{Figure 3}

Rhenium $(A, B)$ and molybdenum $(C, D)$ mass balance model results based on Gordondale Member authigenic metal enrichments to determine seafloor areas of anoxia $\left(A_{\text {anoxic }}\right)$ and euxinic $\left(A_{\text {euxinic }}\right)$ prior to $(B, D)$ and during $(A, C)$ the Toarcian Oceanic Anoxic Event (T-OAE). All model results were determined using a bulk mass accumulation rate calculated from the median duration of the T-OAE $(400 \mathrm{kyr})^{3-5}$. Pre $\mathrm{N}$-CIE model results (B,D) were determined with river inputs set to modern $\left(4.29 \times 10^{5} \mathrm{~mol} \mathrm{Re} / \mathrm{yr} ; 3.00 \times\right.$ $\left.10^{8} \mathrm{~mol} \mathrm{Mo} / \mathrm{yr}\right)^{18,24,25}$, while $\mathrm{N}$-CIE intervals $(\mathrm{A}, \mathrm{C})$ were determined with river input set to 3 -times modern ${ }^{10}$. Dashed lines are mean authigenic metal enrichments for the stratigraphic intervals and shaded areas are \pm 1 standard deviation.

\section{Supplementary Files}

This is a list of supplementary files associated with this preprint. Click to download.

- kunertkendallsupplementaryinformation.docx 